\title{
CLIMATE CHANGE EFFECT ON WATER RESOURCES USING CLIMATE MODEL DATA OF INDIAN RIVER BASIN
}

\author{
Naga Sowjanya.P1, Venkat Reddy.K ${ }^{2}$, Shashi..M ${ }^{3}$ \\ ${ }^{1}$ Research Scholar, National Institute of Technology Warangal, \\ sowjy127@gmail.com \\ ${ }^{2}$ Assisstant Professor, National Institute of Technology Warangal, \\ kvreddy@nitw.ac.in \\ ${ }^{3}$ Assisstant Professor, National Institute of Technology Warangal, \\ mes.shashi@gmail.com
}

\begin{abstract}
In context of climate change it is necessary to quantify the impact on water resources for efficient use and management. It generates significant runoff in river basins, which is the main source of water for all sectors. Climate change is the prime influencing factor in occurrence of monsoon that leads to runoff variations in Indian river basins. Hence, it is necessary to assess the impact of climate change on water resources. The ability to estimate the effect of climate change on water resources depends on the availability of climate model database. Present paper focuses on the effects climate change on water resources for the part of Krishna river basin, India using climate model database in Soil and Water Assessment Tool (SWAT) model. SWAT calibration and uncertainty program (SWAT-CUP) is used for the model calibration, sensitivity and uncertainty analysis. The climate model database used in the study is Coordinated Regional Climate Downscaling Experiment (CORDEX) of South Asia downscaled using Global Circulation Models (GCM) of Coupled Model Inter comparison Project Phase 5 (CMIP5). Based on the results it is observed that decrease in the precipitation, minimum temperature and maximum temperature influence the mean monthly stream flow patterns.
\end{abstract}

Keywords: Climate Change, Climate Model Database, SWAT, Water Resources

\section{INTRODUCTION}

Anthropogenic perturbations play a significant role in climate change impact on temperature and precipitation in global scale. These changes in climate have been investigated and attributed in measurable impacts on the physical environment. Inter annual-to-decadal variability of warming because of increase in Temperature(IPCC, 2013) is the mainly identified issue for coming centuries . Most of the mid-latitude land masses are subjected to intense precipitation and increase in global mean surface temperature leads to frequent wet tropical regions by the end of the century,(IPCC, 2013). These changing climate conditions will have dramatic affect on the Water Resources.

Major sectors such as Agriculture, Forestry, Mining, Energy resource extraction, Electric power supply and Public water supply directly rely on Water Resources. The Management of water resources in terms of quantity and quality of water, aquatic ecosystem sustainability is possible only with the accurate information on the spatial variability of water resources and estimation of the potential effects of these changes on water resources. Hence, it is necessary to project the possible effects due to climate change in hydrology of water resources using hydrological modelling (Narsimhulu et al., 2013, Gosain et al., 2011). The SWAT model is employed to simulate hydrologic processes in different watersheds (Arnold et al., 1998; Neitsch et.al., 2005). Calibration and validation of the model was carried out by applying the SUFI-2 in SWAT-CUP (Abbaspour et.al.,2004, 2007). The ability to assess the effect of runoff under changing climate on water resources depends on the availability of climate model database and Hydrologic Model.

Vagueness of monsoon precipitation has high impact in both temporal and spatial scales, which effects most of the climatic regions over India (Diwan 2002). The goal of the study is to estimate the potential effect of climate change for a part of Krishna River basin. A distributed Hydrologic model, the SWAT model is used by calibrating and validating with the measured stream flow from three gauged sites (Jeong et. al., 2010). Model calibration, validation and uncertainty analysis is carried out using Sequential Uncertainty Fitting Algorithm (SUFI-2). The bias corrected future climatic projections for environmental forcings like temperature and precipitation from various GCMs are used as an input to the SWAT model to estimate the impact of climate change on runoff for a part of Krishna river basin.

\section{Study Area}

The Krishna River contains a total of 7 sub basins and its tributaries form an important integrated drainage system in the central portion of the Indian Peninsula . The present work is carried out in Upper Krishna basin a part of the 
Krishna River Basin which includes three sub basins Upper Bhima, Lower Bhima and Upper Krishna (Figure 1)

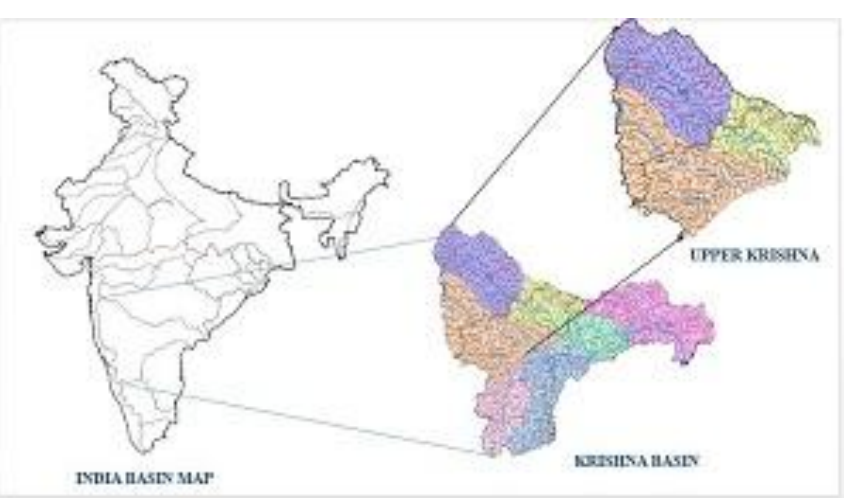

Figure 1: Location Map of the Upper Krishna basin

\section{Data sets}

Geospatial data :

- $30 \mathrm{~m} * 30 \mathrm{~m}$ grid Digital Elevation Model (DEM) is used to trace the watershed boundary and analyze the drainage pattern of the terrain. It is downloaded from Advanced Space borne Thermal Emission and Reflection Radiometer (ASTER) of NASA.

- Landuse / Landcover is downloaded from http://www.waterbase.org/ . Waterbase Land use data contains crop specific digital layers, suitable for use in GIS.

- Soil Map and its characteristics is downloaded from http://www.waterbase.org/Other datasets:

- Daily Stream flow data measured by Central Water Commission (CWC) at 20 Hydro observation sites recorded from 1970 to 2005 were used for SWAT calibration and validation.

Climate data used in the present study are obtained from two sources.

- Observed Precipitation (PCP), Maximum and Minimum Temperatures (Temp) of $0.5^{\circ} * 0.5^{\circ}$ grids is obtained from Indian Meteorological Department (IMD), Pune for the period 1970 to 2005 .

- Climate data of 2 GCMs named Community Climate System Model (CCSM) and Centre National de Recherches Meteorologiques (CNRM) from Coordinated Regional Climate Downscaling Experiment (CORDEX) of South Asia outputs of $0.5^{\circ} * 0.5^{\circ}$ resolution for Base line (1970 - 2005), Future (2006 - 2040) for Representative Concentration Pathway (RCP) 4.5 scenario obtained from Centre for Climate Change Research (CCCR), Indian Institute of Meteorology (IITM) Pune.

\section{Methodology}

The work flow of the methodology is as shown in the Figure 2. The SWAT model is set up taking geospatial data and weather data as inputs. SWAT CUP is used to calibrate and validate the model with the observed data. The simulations are carried out in the calibrated and validated SWAT model with the bias corrected climate data. The analysis is carried out to predict the effect of climate change on water resources of upper krishna.

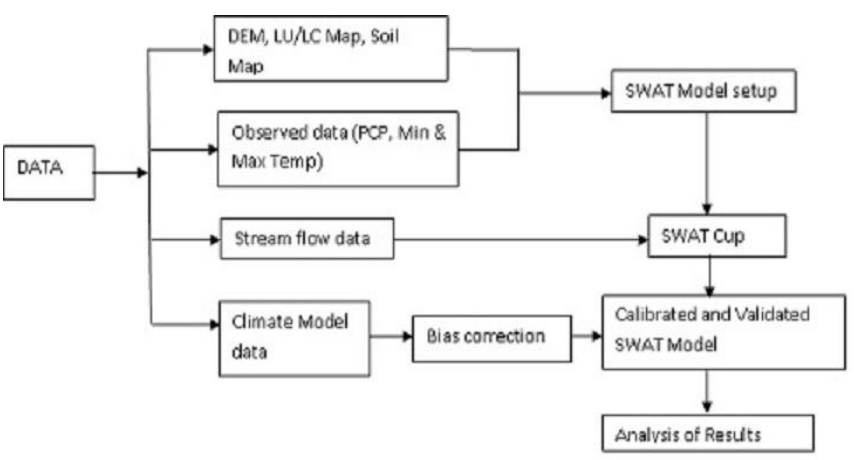

Figure 2: Workflow of the Methodology

\section{Swat Model Setup}

The SWAT is employed to simulate hydrologic processes in three watersheds of the Upper Krishna. SWAT model is set up for the Upper Krishna with the obtained Geospatial data and 51 sub basins are delineated in Upper Krishna (Figure 3 ). Based on the type of soil and landuse classification, the sub basins have been further divided into 911 Hydrologic Response Units (HRU) . The Curve number (CN) method used for generating surface runoff from observed climate data. The first five years of simulations i.e., from 1970 to 1974 of the observed climate data are used as a warm up period.

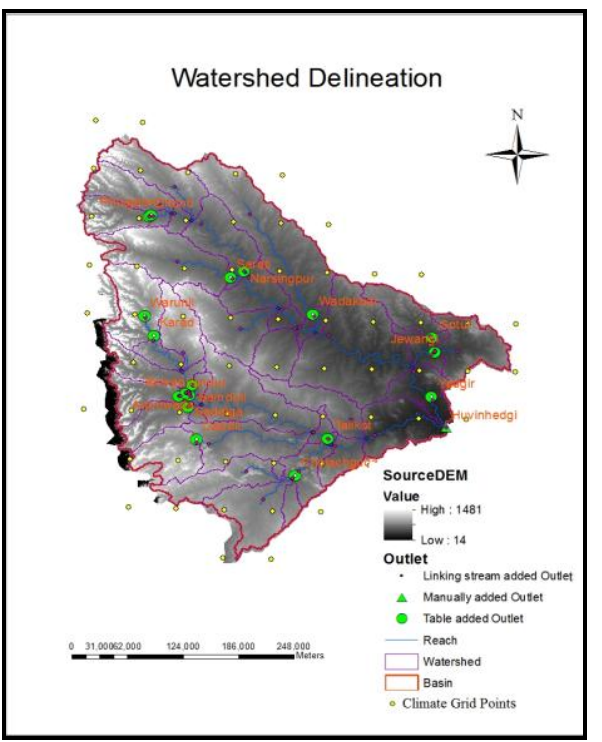

Figure 3: Watershed delineation with the climate grid points

\section{SWAT-CUP}

The model is calibrated for 1976 to 1990 and validated for 1991 - 2005 using SUFI-2 at each watershed outlet i.e., Arjunwada, Narsingpur and Huvinhedgi. Calibration at the watershed outlet is carried out using 17 parameters which affect the runoff. Initial ranges of parameters are identical for all the watersheds and the optimal ranges of 
Table 1: Parameter ranges for SWAT calibration and parameter significance

\begin{tabular}{|c|c|c|c|c|c|c|c|c|c|c|c|}
\hline \multirow[t]{2}{*}{ Parameter } & \multicolumn{2}{|c|}{ Initial Range } & \multicolumn{3}{|c|}{$\begin{array}{l}\text { Arjunwada } \\
\text { Final Range }\end{array}$} & \multicolumn{3}{|c|}{$\begin{array}{l}\text { Narsingpur } \\
\text { Final Range } \\
\end{array}$} & \multicolumn{3}{|c|}{$\begin{array}{l}\text { Huvinhedgi } \\
\text { Final Range }\end{array}$} \\
\hline & Min & $\operatorname{Max}$ & Min & $\operatorname{Max}$ & Fitted & Min & $\operatorname{Max}$ & Fitted & Min & $\operatorname{Max}$ & Fitted \\
\hline $\mathrm{CN} 2$ & -0.2 & 0.2 & 0.07 & 0.15 & 0.812 & 0 & 0.15 & 0.0352 & -0.241 & -0.0013 & -0.2206 \\
\hline ALPHA_BF & -0.7217 & 0.1851 & -0.7217 & 0.1851 & -0.0143 & 0.1 & 0.3 & 0.109 & -0.721 & 0.1857 & -0.3814 \\
\hline GW_DELAY & 81.558 & 476.017 & 81.558 & 476.016 & 263.00 & 340 & 400 & 387.8 & 87 & 477 & 463.35 \\
\hline GWQMN & -0.0073 & 1.5187 & -0.0073 & 1.5187 & 1.2440 & 0.9 & 1.517 & 1.4398 & -0.007 & 1.517 & 0.0308 \\
\hline GW_REVAP & 0.156 & 0.3056 & 0.95 & 20.00 & 17.333 & 0.156 & 0.3056 & 0.2734 & 0.156 & 0.3056 & 0.2689 \\
\hline ESCO & 0.9341 & 1.0456 & 0.8 & 1 & 0.932 & 0.95 & 1 & 0.9522 & 0.934 & 1.0456 & 0.9636 \\
\hline SOL_K & 0.1377 & 0.9879 & 70 & 150 & 87.599 & 25 & 150 & 31.875 & 0.137 & 0.9879 & 0.92413 \\
\hline ALPHA_BNK & 0.062 & 0.9712 & 0.95 & 1 & 0.985 & 0.4 & 0.6 & 0.419 & 0.062 & 0.971 & 0.7482 \\
\hline SOL_AWC & -0.1457 & 0.1453 & 0.3 & 0.8 & 0.49 & 0.1 & 0.2 & 0.1475 & -0.145 & 0.15 & 0.1219 \\
\hline REVAPMN & 1.5544 & 6.0645 & 1.5244 & 6.0645 & 2.8864 & 200 & 300 & 219.5 & 200 & 400 & 249 \\
\hline SOL_BD & 0.0543 & 0.6958 & 1.2 & 2 & 1.952 & 0.9 & 2.5 & 2.268 & 0.0543 & 0.6958 & 0.3269 \\
\hline OV_N & -0.1663 & -0.0389 & -0.1663 & 0.0389 & -0.0822 & 19 & 30 & 29.174 & -0.166 & 30 & 28.642 \\
\hline CH_K2 & 18.7187 & 103.942 & 5 & 20 & 11.3 & 20 & 100 & 54.799 & 18.709 & 104 & 64.340 \\
\hline EPCO & -0.815 & 0.1379 & -0.815 & 0.1379 & -0.4147 & 0 & 0.14 & 0.0469 & -0.82 & 0.14 & -0.4792 \\
\hline HRU_SLP & 0.1079 & 0.2128 & 0.1079 & 0.2128 & 0.2023 & 0.1079 & 0.2128 & 0.1147 & 0.1079 & 0.2128 & 0.11157 \\
\hline CH_N2 & -0.0888 & 0.0885 & 0 & 0.3 & 0.042 & 0.06 & 0.0885 & 0.0812 & -0.088 & 0.0885 & 0.08584 \\
\hline SLSUBBSN & 0.1324 & 0.2681 & 0.1324 & 0.2681 & 0.17311 & -0.133 & 0.2681 & -0.002 & -0.133 & 0.2681 & 0.22995 \\
\hline
\end{tabular}

CN2: SCS runoff curve number ; ALPHA_BF: Baseflow alpha factor (days); GW_DELAY: Groundwater delay time(days); GWQMN: Threshold depth of water in the shallow aquifer required for returnflow to ocuur $(\mathrm{mm})$; GW_REVAP: Groundwater "revap" coefficient; ESCO : Soil evaporation compensation factor; SOL_K: Saturated hydraulic conductivity in main channel alluvium $(\mathrm{mm} / \mathrm{hr})$; ALPHA_BNK: Baseflow alpha factor for bank storage (days); SOL_AWC: Available water capacity of the soil layer (mm); REVAPMN: Threshold depth of water in the shallow aquifer for "revap" or percolation to the deep aquifer to occur(mm); SOL_BD: Moist Bulk density $\left(\mathrm{Mg} / \mathrm{m}^{3}\right) ; O V_{-} N$ : Mannings " $n$ " value for overland flow; CH_K2: Effective hydraulic conductivity in main channel alluvium $(\mathrm{mm} / \mathrm{hr})$; EPCO: Plant uptake compensation factor; HRU_SLP: Average slope steepness; CH_N2:Mannings " $n$ " value for the main channel; SLSUBBSN: Average slope length.

Parameters differ from calibration as shown in the Table 1.

Two statistical parameters (Nash-Sutcliffe coefficient- E and the coefficient of determination- $\mathrm{R}^{2}$ ) are used to evaluate the model efficiency. The SUFI- 2 iterations are carried out to get the optimum set of parameters with the maximum $\mathrm{E}$ and $\mathrm{R}^{2}$ values.

The SWAT simulations are carried out with the last iteration best set parameters with the observed and the Model climate data. The climate model data of the study area is retrieved for 62 grid points (Figure 2) of $0.5^{\circ} * 0.5^{\circ}$ resolution and bias corrected in R Programming Environment. The bias corrected climate Model databases obtained are applied in calibrated SWAT Model to simulate the hydrologic components of the Upper Krishna for the Historic (1970 2005) and Future (2006 - 2040) periods.

Measured Stream flows during 1975-1990 at the CWC stations Arjunwada, Narsigpur and Huvinhedgi are used to calibrate SWAT. Flow validation is conducted using the stream flow data for the period from 1991 to 2005 .

The SWAT simulations are carried out for historic and future periods with the bias corrected downscaled climate model data. The climate model variables will have significant deviations from the observed data that propogates to the significant difference between the simulated and climate model streamflows. These differences in the streamflow is corrected by applying the Quantile mapping method, which uses the empirical probability distributions (Equation 1) for the observed and simulated flows to remove biases. $\quad \mathrm{Z}_{\mathrm{j}}^{\mathrm{i}}=\mathrm{F}_{\mathrm{oj}}{ }^{-1}\left(\mathrm{~F}_{\mathrm{sj}}\left(\hat{\mathrm{Y}}_{\mathrm{j}}^{\mathrm{i}}\right)\right)$

(1)

where $Z_{j}^{i}$ is the corrected stream flow for the month $j$ of the $i^{\text {th }}$ year, $F_{o j}{ }^{-1}$ is the cumulative distribution function of the observed monthly runoff for month $\mathrm{j}, \mathrm{F}_{\mathrm{sj}}$ is the cumulative distribution function of the corresponding simulated runoff from the historic simulation, $\hat{\mathrm{Y}}_{\mathrm{j}}^{\mathrm{i}}$ is the uncorrected stream flow produced for month $\mathrm{j}$ of the $\mathrm{i}^{\text {th }}$ year.

\section{RESULTS AND DISCUSSION}

The mean monthly variations of observed and model climate variables represents falling trend for minimum temperature and precipitation compared to the observed variables (Figure 4). 


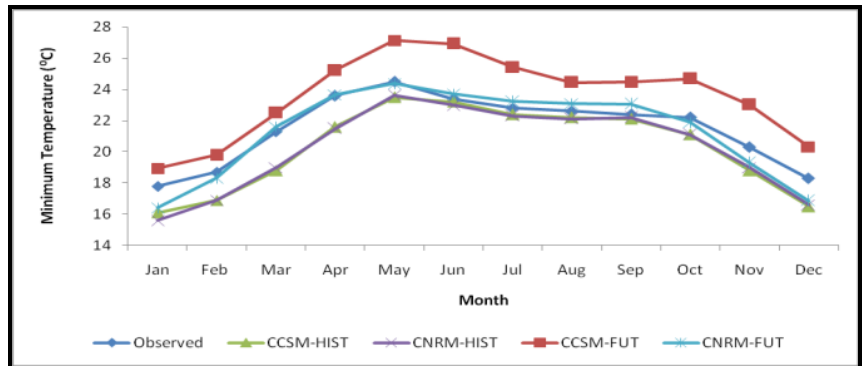

(a)

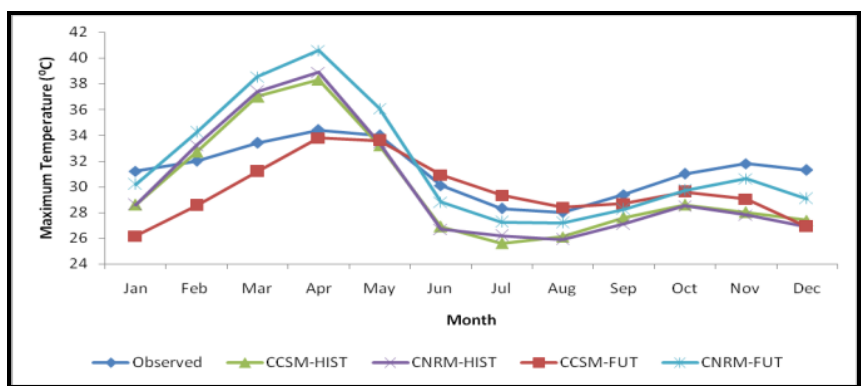

(b)

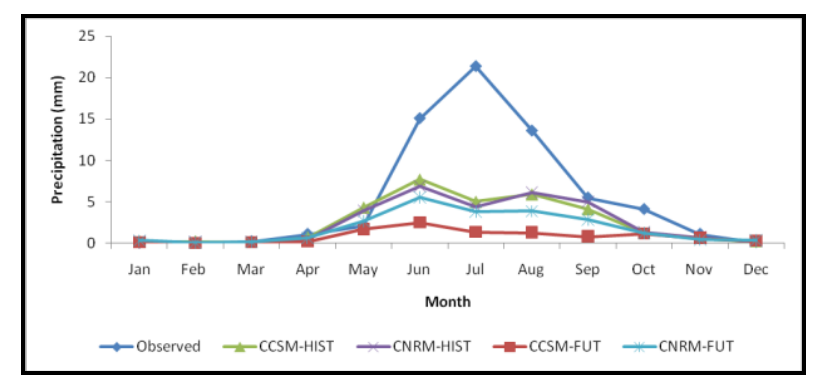

(c)

Figure 4: Mean Monthly variations of observed and model climate variables (a) Minimum Temperature (b)Maximum Temperature (c) Precipitation.

The analysis of the mean monthly variations of the climate variables shows decrease trend in precipitation, minimum temperature and maximum temperature for the historic period. Lower Rainfall trends are observed in the future projection period with the increased minimum and maximum temperatures.

\section{SWAT Calibration and Validation}

The Measured Stream flows during 1975-1990 at the CWC stations Arjunwada, Narsigpur and Huvinhedgi were used to calibrate SWAT. Flow validation was conducted using the stream flow data for the period from 1991 to 2005 . Calibrated (Figure 5) and Validated (Figure 6) monthly stream flow at the these stations shows the similar pattern. Simulated monthly streamflows from calibrated and validated SWAT shows reasonable agreement with the measurements of the CWC guage stations. The $\mathrm{R}^{2}$ and $\mathrm{E}$ values of the Arjunwada, Narsingpur and Huvinhedgi for the calibration and validation periods are as shown in Figure 5. During calibration, the $\mathrm{R}^{2}$ value of the two among three stations has exceeded 0.6 and around 0.5 of $E$ values. Three stations has the $\mathrm{R}^{2}$ value of around 0.5 and $\mathrm{E}$ of around 0.43 for two stations respectively, during validation period.

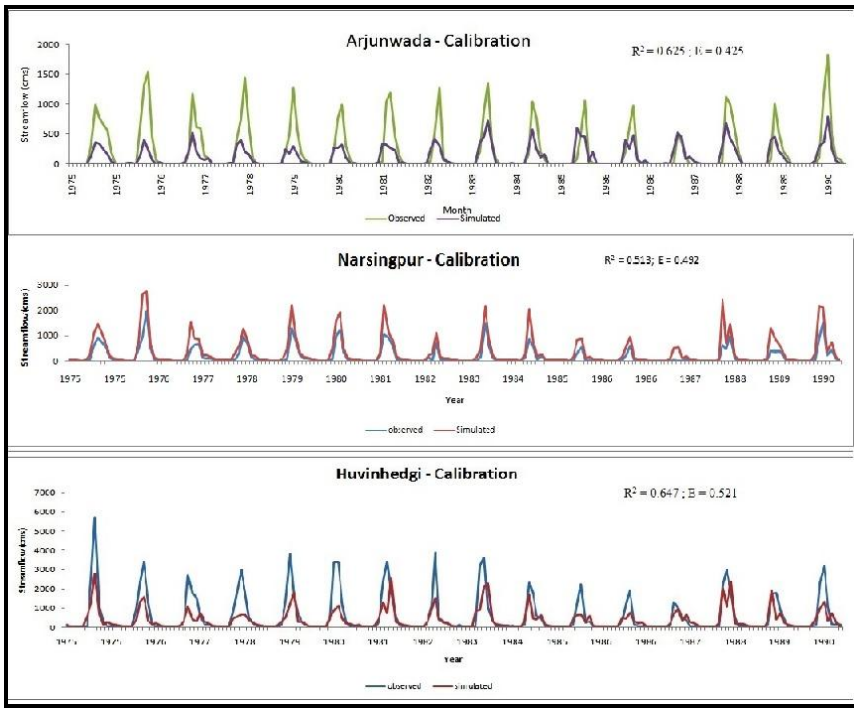

Figure 5 : The observed and simulated monthly stream flows of the Arjunwada, Narsingpur and Huvinhedgi for the Calibration period (1975 -1990).

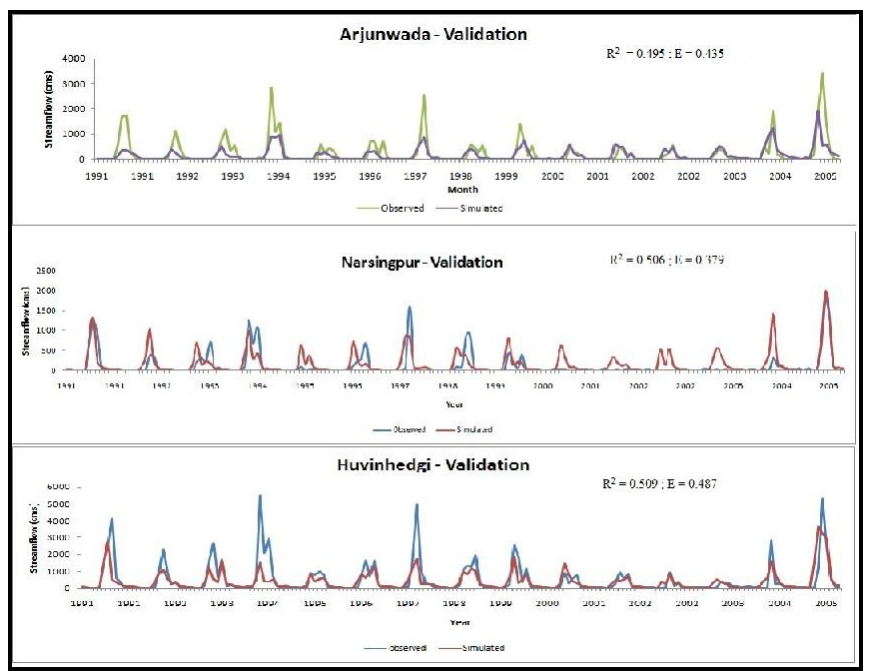

Figure 6 : The observed and simulated monthly stream flows of the Arjunwada, Narsingpur and Huvinhedgi for the Validation period (1991 -2005)

The calibrated SWAT Model was run with the bias corrected climate data for the period 1970 - 2005, 2006 to 2040 obtained from CCSM and CNRM. The mean monthly variations of the simulated stream flows for the Historic and Future periods are as shown in the Figure 7.

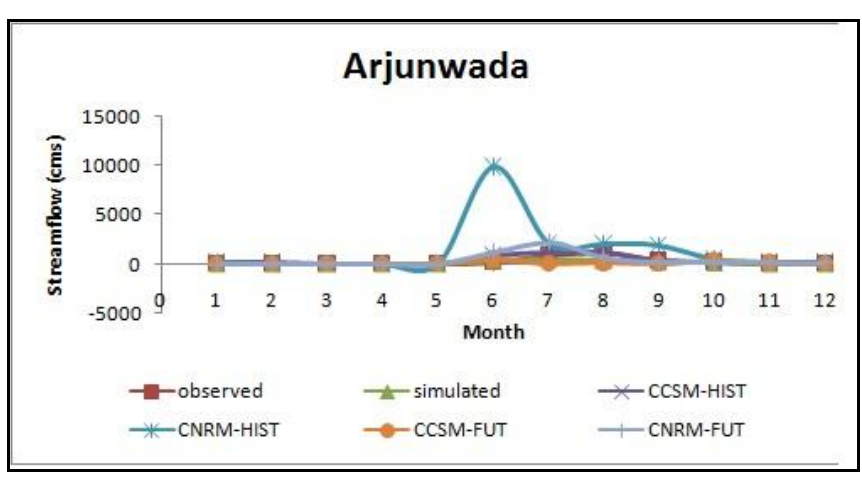

(7a) 


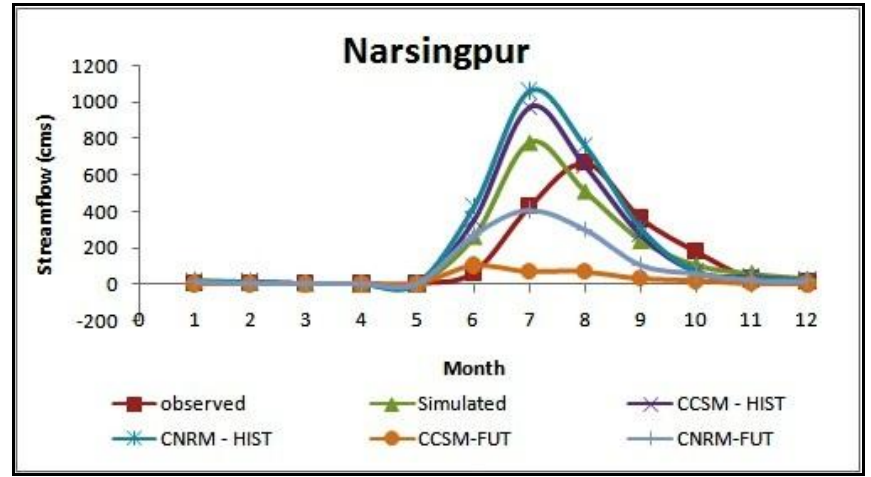

(7b)

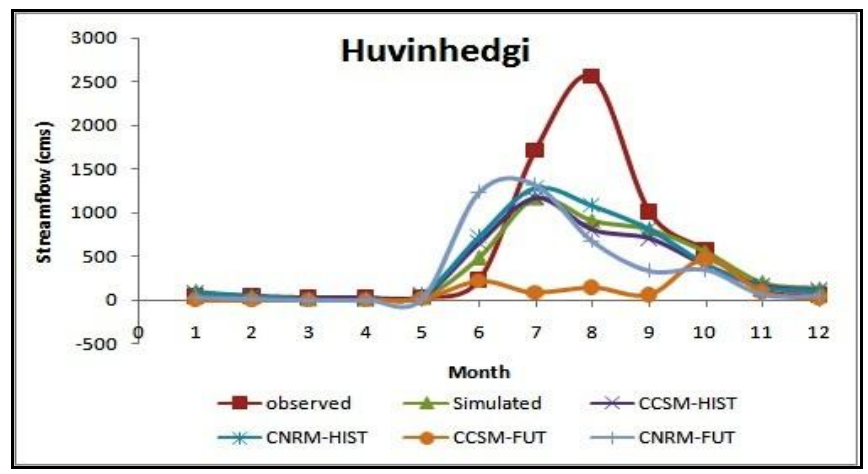

$(7 \mathrm{c})$

Figure 7: Mean monthly variations of the streamflow for baseline and future periods (a) Arjunwada (b) Narsingpur (c) Huvinhedgi.

\section{CONCLUSION}

The effect of the climate change on the stream flow variability of the upper krishna is evaluated by comparing the baseline climate conditions from the observed and climate model data. The annual average percentage change in precipitation of CCSM and CNRM models from 1970 to 2005 and 2006 to 2040 ranges from $-20.55 \%$ to $-47.91 \%$ and $-22.15 \%$ to $-13.23 \%$. The mean minimum and maximum temperature differences between the CCSM and CNRM models for 1970 to 2005 and 2006 to 2040 are $-1.225^{\circ} \mathrm{C}$ to $2.08{ }^{\circ} \mathrm{C},-1.24{ }^{\circ} \mathrm{C}$ to $-1.562{ }^{\circ} \mathrm{C},-1.25{ }^{\circ} \mathrm{C}$ to $-0.197{ }^{\circ} \mathrm{C}$ and $1.19{ }^{\circ} \mathrm{C}$ to $0.465^{\circ} \mathrm{C}$ respectively.

Mean monthly variations of the simulated climate models stream flow for the historic and future periods shows increased stream flow in the historic period of the CNRM model at Arjunwada. The historic period simulated stream flows for both the models shows increase in the stream flow and decreased stream flow for the future period at Narsingpur and Huvinhedgi.

\section{REFERENCES}

[1] Abbaspour, K.C., Johnson, C.A., van Genuchten, M.T., 2004. Estimating uncertain flow and transport parameters using a sequential uncertainty fitting procedure. Vadose Zone J. 3 (4), 1340-1352.
[2] Abbaspour, K.C., Jing Yang., Ivan Maximov., Rosi Siber., Konrad Bogner, Johanna Mieleitner., Juerg Zobrist., Raghavan Srinivasan., 2007. Modelling hydrology and water quality in the prealpine/ alpine Thur watershed using SWAT. J. Hydrol. 333 (2-4), 413-430.

[3] Arnold, J.G., Srinivasan, R., Muttiah, R.S., Williams, J.R., 1998. Large area hydrologic modeling and assessment - Part 1: Model development. J. Am. Water Resour.Assoc. 34 (1), 73-89.

[4] Diwan, PL., 2002. Vagaries of Monsoon: Water Crisi and its Management. Press release( September 20, 2002). government of India, Press Information Bureau, New Delhi.

[5] Gosain, AK., Rao, S., Arora, A., 2011. Climate change impact Assessment of Water Resources in India. Current Science, Vol. 101, No.3.

[6] IPCC. 2013. Climate Change 2013: The Physical Science Basis. Contribution of Working Group I to the Fifth Assessment Report of the Intergovernmental Panel on Climate Change. Stocker,T., Qin. D., Plattner, G., Tignor, M., Allen. S., Boschung, J., Nauels, A., Xla, Y., Bex, V., Midgley, P., (Eds.), Cambridge University Press, Cambridge, UK and New York, USA.

[7] Jeong, J., Kannan, N., Arnold, J., Glick, R., Gosselink, L., Srinivasan, R., 2010. Development and Integration of Sub - hourly Rainfall - Runoff Modelling Capability within a Watershed Model. Water Resour Manage, Vol. 24, Issue 15, 4505 - 4527.

[8] Narsimhulu, B., Ashvin, K., Chachar, BR..,2013. Assessment of Future Climate change Impacts on Water Resources of Upper Sind River Basin, India using SWAT Model.Water Resour Manage Vol. 27, Issue 10, 3647 - 3662.

[9] Neitsch, S.L., Arnold, J.G., Kiniry, J.R., Srinivasan, R., Williams, J.R., 2005. Soil and Water Assessment Tool Input/Output File Documentation. Verison 2005. Blackland Research Center, Texas Agricultural Experiment Staion, Texas. 